\title{
Nanowires Nickel Oxide and Nanospherical Manganese Oxide Synthesized via Low Temperature Hydrothermal Technique for Hydrogen Peroxide Sensor
}

\author{
Suriani Ibrahim, ${ }^{1,2}$ Tawatchai Charinpanitkul, ${ }^{3}$ Eiry Kobatake, ${ }^{4}$ and Mana Sriyudthsak ${ }^{1}$ \\ ${ }^{1}$ Department of Electrical Engineering, Chulalongkorn University, Bangkok 10330, Thailand \\ ${ }^{2}$ Department of Mechanical Engineering, University of Malaya, 50603 Kuala Lumpur, Malaysia \\ ${ }^{3}$ Department of Chemical Engineering, Chulalongkorn University, Bangkok 10330, Thailand \\ ${ }^{4}$ Department of Environmental Chemistry and Engineering, Tokyo Institute of Technology, Kanagawa 226-8501, Japan
}

Correspondence should be addressed to Suriani Ibrahim; suria2383@gmail.com and Mana Sriyudthsak; mana.s@chula.ac.th

Received 30 September 2015; Revised 11 December 2015; Accepted 18 January 2016

Academic Editor: Artur M. S. Silva

Copyright (C) 2016 Suriani Ibrahim et al. This is an open access article distributed under the Creative Commons Attribution License, which permits unrestricted use, distribution, and reproduction in any medium, provided the original work is properly cited.

\begin{abstract}
Binary catalyst nickel oxides $(\mathrm{NiO})$ and manganese oxides $(\mathrm{MnO})$ were prepared individually via hydrothermal route. The catalysts were characterized by scanning electron microscope (SEM), Brunauer-Emmett-Teller (BET) analysis, cyclic voltammetry (CV), and amperometry. Morphology studies revealed physical structure of nanowires nickel oxide and spherical manganese oxide with estimated length of $0.3-2.3 \mu \mathrm{m}$ and diameter of $0.2-0.8 \mu \mathrm{m}$, respectively. Surface areas obtained for nickel oxide and manganese oxide were $68.9 \mathrm{~m}^{2} \mathrm{~g}^{-1}$ and $45.2 \mathrm{~m}^{2} \mathrm{~g}^{-1}$, respectively. Cyclic voltammetry exhibits electrochemical responses corresponding to the electrode surfaces. The linear responses of the binary catalyst modified gold electrodes with $\mathrm{NiO}-\mathrm{MnO}$ were observed in the concentration range from $31.8 \mu \mathrm{M}$ to $0.5 \mathrm{mM}$ with the detection limit of $62.5 \mu \mathrm{M}$.
\end{abstract}

\section{Introduction}

Hydrogen peroxide was employed in many applications including pharmaceutical, food, and industry applications. It can also be a biological marker for certain diseases like cancer, aging, and renal diseases [1-4]. Hence, rapid, sensitive, and accurate determination of $\mathrm{H}_{2} \mathrm{O}_{2}$ is extremely important. Amperometry is the most attractive techniques to detect hydrogen peroxide because of high sensitivity, low cost, and its simplicity [5]. Nanomaterials gained a lot of interest among researchers due to their excellent mechanical and electrical properties. To increase the sensitivity of the sensor, nanoparticles (NPs) are the best candidate due to their large specific surface area and biocompatibility [6]. Nickel oxide $\left(\mathrm{NiO}_{x}\right)$ was intensively studied because of its high electron transfer capability and good biological compatibility [7-10]. However, the performance of these electrodes could be limited by surface poisoning [11]. Some studies revealed that, by using multicomponent surface compositions, especially the metal composite can overcome surface poisoning problems
$[12,13]$. Manganese oxide $\left(\mathrm{MnO}_{x}\right)$ is a very attractive metallic oxide and widely used in fuel cells, sensor, catalyst, and metal coating [14-17]. Moreover, $\mathrm{MnO}_{x}$ was also used as a cocatalyst material in biosensor and fuel cells [18]. Binary catalysts are very attractive materials for their unique properties, when compared to single catalyst. For example, Ding et al. fabricated $\mathrm{NiO}$ hybrid nanowires with uniformly distributed $\mathrm{Ag}$ and Au NPs, enhancing glucose biosensing performance. Polydopamine has been widely used as a coating agent for various inorganic and organic substrates [19,20]. Dopamine will self-polymerize at alkaline $\mathrm{pH}$ oxidizing and forming thin polydopamine films. Some researchers are working on binary catalyst $\mathrm{NiO}-\mathrm{MnO}$ for various applications [21-24]. For example, Zhang et al. synthesized $\mathrm{MnO}-\mathrm{NiO}$ composite oxide catalyst for lean methane combustion at low temperature. However, to the best of our knowledge, there are not many published reports on the binary catalyst NiO$\mathrm{MnO}$ for hydrogen peroxide detection. Therefore, this work could be beneficial for researchers who make studies on catalyst for electrochemical sensors. We report on fabrication 


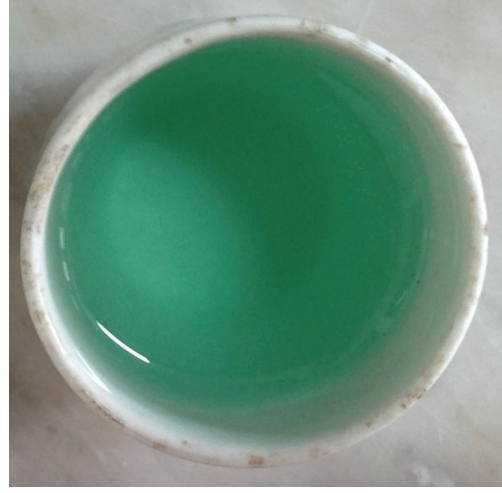

(a)

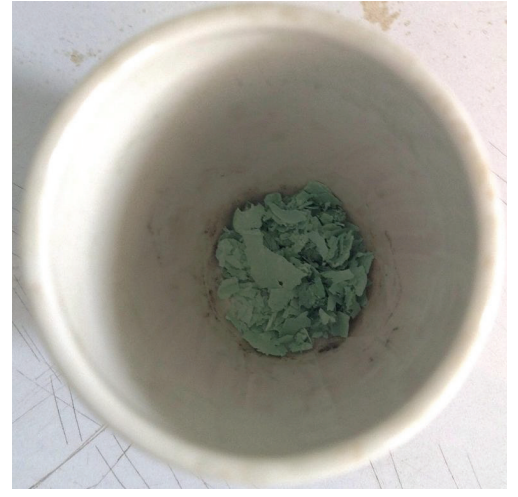

(b)

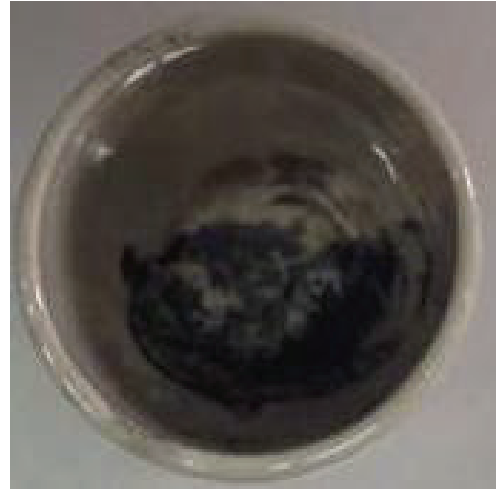

(c)

FIgURE 1: (a) Precursor; (b) nickel hydroxide; (c) nickel oxide.

of polydopamine-nickel oxide-manganese oxide composite on gold electrode to detect low concentrations $(31.8 \mu \mathrm{M}$ to $0.5 \mathrm{mM}$ ) of hydrogen peroxide.

\section{Experimental}

2.1. Chemical and Reagents. All chemicals were analytical grade reagents and employed as received without further purification. $\mathrm{NiO}$ and $\mathrm{MnO}$ were synthesized from $\mathrm{Ni}\left(\mathrm{CH}_{3} \mathrm{COO}\right)_{2} \cdot 4 \mathrm{H}_{2} \mathrm{O}(99 \%), \mathrm{Mn}\left(\mathrm{CH}_{3} \mathrm{COO}\right)_{2} \cdot 4 \mathrm{H}_{2} \mathrm{O}(98 \%)$, and $\mathrm{KMnO}_{4}$ and obtained from Aldrich. Dopamine was obtained from Sigma. Hydrogen peroxide (50\%) and ethylene glycol were obtained from domestic supplier. All solutions were prepared with deionized water. Phosphate buffer solutions $(\mathrm{pH} 8.4$ and $\mathrm{pH}$ 7.4) were used for the modified electrodes preparation and measurement.

2.2. Apparatus. A binary catalyst was individually prepared by using Muffle Furnaces, P80-Series. The material characterizations testing was performed using Brunauer-EmmettTeller (BET) BELSORP-mini II, scanning electron microscope (SEM), and LEO 1450VPSE. For sensor fabrication, 2-electrode system was used; both working and counter electrodes were made from gold. The electrode was obtained from Bioptik Company (Taiwan). The electrochemical tests were performed by using home-made potentiostat. For voltammetry testing, the potential was swept between $-1 \mathrm{~V}$ and $+1 \mathrm{~V}$ with the scan rate of $50 \mathrm{mV} / \mathrm{s}$. The solution for voltammetry testing was $0.1 \mathrm{M}$ phosphate buffer, $\mathrm{pH}$ 7.4. For amperometry testing, the applied potential was $0.7 \mathrm{~V}$. The concentration of hydrogen peroxide was varied from $31.8 \mu \mathrm{M}$ to $0.5 \mathrm{mM}$.

2.3. Synthesis $\mathrm{NiO}$ and $\mathrm{MnO}$. All experiments were conducted under air atmosphere. Nickel oxide and manganese oxide were prepared by hydrothermal technique. To prepare nickel oxide $(\mathrm{NiO}), 0.1 \mathrm{M}$ of $\mathrm{Ni}\left(\mathrm{CH}_{3} \mathrm{COO}\right)_{2} \cdot 4 \mathrm{H}_{2} \mathrm{O}$ were dissolved in a mixed solvent of deionized water and ethylene glycol with a ratio $(1: 1)$ as shown in Figure 1(a). The solvent was transferred into the stainless steel close mould. The furnace was maintained at $200^{\circ} \mathrm{C}$ for 7 hours. Nickel hydroxide
$\mathrm{Ni}(\mathrm{OH})_{2}$ was obtained at this stage as shown in Figure 1(b). The product was separated from the solution by filtration process, washed with deionized water and ethanol several times, and finally dried at $120^{\circ} \mathrm{C}$ in the air. The powder was further heated to $400^{\circ} \mathrm{C}$ for 2 hours [25]. Finally, the nickel oxide was obtained as shown in Figure 1(c).

To prepare manganese oxide (MnO), $0.2 \mathrm{M} \mathrm{Mn}\left(\mathrm{CH}_{3} \mathrm{COO}\right)_{2}$ and $0.2 \mathrm{M} \mathrm{KMnO}_{4}$ were individually dissolved in deionized water. These solutions were mixed together, with the molar ratio of 1:1 as shown in Figure 2(a). The mixed solution was loaded into the stainless steel mould. During the hydrothermal reaction, the heating temperature setting was $125^{\circ} \mathrm{C}$ for 3 hours [26]. The black precipitates were obtained and collected through filtration and washed with deionized water and finally dried at $120^{\circ} \mathrm{C}$ for 10 hours. Finally, the manganese oxide was obtained as shown in Figure 2(b).

2.4. Modified Gold Electrodes. For single catalyst modified gold electrodes, dopamine solution was prepared by mixing $1 \mathrm{mg}$ dopamine with $1 \mathrm{~mL}$ phosphate buffer ( $\mathrm{pH}$ 8.4). Single catalyst solutions were individually prepared by mixing $1 \mathrm{mg}$ of each nickel oxide and manganese oxide in $1 \mathrm{~mL}$ ethanol solution. Single catalyst modified electrodes were prepared by dropping $10 \mu \mathrm{L}$ of single catalyst suspension on the electrodes surface and dried at room temperature (first layer). This type of modified gold electrodes was used in cyclic voltammetry testing. Then, for amperometry testing, $6 \mu \mathrm{L}$ of dopamine solution was dropped onto metal oxide layer and dried at room temperature with exposure to the room light for 7 hours (second layer).

For binary catalyst modified gold electrode, $1 \mathrm{mg}$ nickel oxide and $1 \mathrm{mg}$ manganese oxide were mixed in $1 \mathrm{~mL}$ of ethanol solution. Then $10 \mu \mathrm{L}$ of this suspension was dropped on the electrode surface and dried at room temperature (first layer). This type of modified gold electrodes was used in cyclic voltammetry testing. Then, for amperometry testing, $6 \mu \mathrm{L}$ of dopamine solution was dropped onto metal oxide layer and dried at room temperature with exposure to the room light for 7 hours (second layer).

Schematic of modified electrode for amperometry testing is shown in Figure 3. 


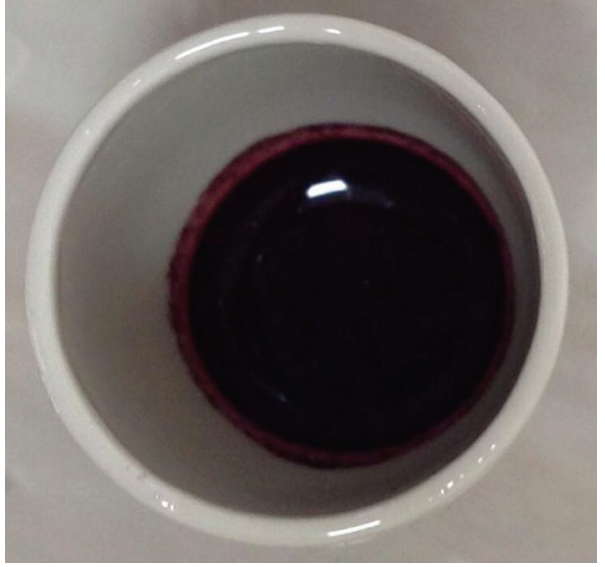

(a)

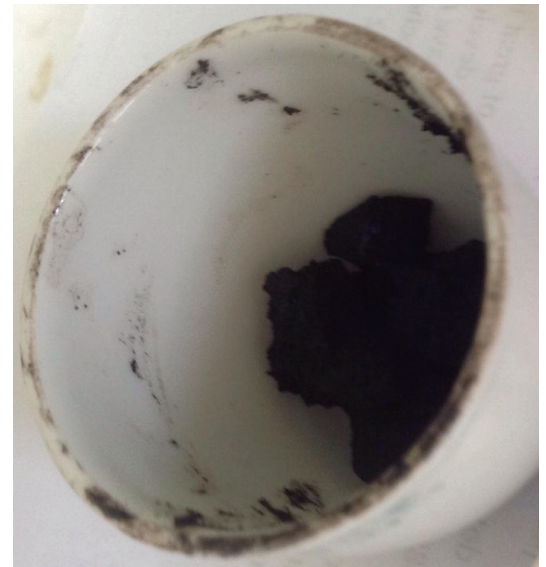

(b)

Figure 2: (a) Precursor; (b) manganese oxide.

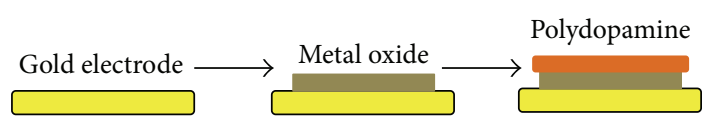

FIGURE 3: Schematic of modified gold electrode (layer by layer).

\section{Results and Discussion}

Figure 4 presents SEM images taken from the synthesized nanoparticles. Figure 4(a) shows an image of the nickel oxides. The nanowires nickel oxides are in agglomerated form. The estimated wires length is between $0.3-2.3 \mu \mathrm{m}$. Figure 4(b) shows an image of the manganese oxides. The structure of manganese oxides is in spherical shape with estimated diameters size between $0.2-0.8 \mu \mathrm{m}$. The specific surface areas of the synthesized nanoparticles were also estimated using Brunauer-Emmett-Teller (BET) analysis. The BET specific surface areas of $\mathrm{NiO}$ and $\mathrm{MnO}$ were $68.9 \mathrm{~m}^{2} \mathrm{~g}^{-1}$ and $45.2 \mathrm{~m}^{2} \mathrm{~g}^{-1}$, respectively. In our work, $\mathrm{NiO}, \mathrm{MnO}$, and their mixture were used as a catalyst for hydrogen peroxide detection. Polydopamine was used as a coating material for fixing metal oxide on the electrode surface. Therefore, the modified electrode with polydopamine can be used for multiple measurement. Dopamine is a simple and easy coating material because it can undergo self-polymerization under effects of light, $\mathrm{pH}$, and heat. Dopamine will undergo several transformation phases before forming a polymer. Mechanism of dopamine polymerization is reported by Jang et al. [27]. Polymerization of dopamine can also be observed by the colour change from clear to darkish brown [28].

Figure 5 shows XRD patterns of manganese oxide and the nickel oxide. It was found that the nickel oxide shows very high and sharp crystalline peaks compared to the manganese oxide. The crystalline peak from another works were also matched in the same figure [29-31]. This nickel oxide shows only the divalent form (NiO) [29]. The manganese oxide was a mixture of $\mathrm{Mn}_{3} \mathrm{O}_{4}$ and $\mathrm{MnO}_{2}[30,31]$. The crystallinity of most oxides is related to the heating temperature during the preparation. Our nickel oxide shows higher crystallinity than manganese oxide because they were prepared at $400^{\circ} \mathrm{C}$ and $125^{\circ} \mathrm{C}$, respectively.

The electrochemical properties of modified gold electrodes without polydopamine were investigated using cyclic voltammetry $(\mathrm{CV})$ as shown in Figure 6. The testing was conducted in $10 \mathrm{mM}$ phosphate buffer with $50 \mathrm{mV} / \mathrm{s}^{-1}$ scan rate. Both bare gold electrode and polydopamine modified gold electrode exhibit almost no voltammetric response. This implies that electron transfers at both of these electrodes surfaces are very slow. The current at the electrode with polydopamine was a little bit lower than the bare electrode. The coverage of polydopamine layer might reduce the electron transfer. However, it is necessary for immobilization of the nickel oxide and manganese oxide. After deposition of single or binary catalysts on the electrode surfaces, the voltammetric responses were greatly improved. Currents show a dramatic increase when $\mathrm{MnO}, \mathrm{NiO}$, or $\mathrm{NiO}+\mathrm{MnO}$ catalysts were coated on the gold electrodes surface.

However, single and binary catalysts exhibit different electrochemical responses as shown in Figure 5. Modified electrode with single catalyst $\mathrm{NiO}$ showed small redox peaks at $0.50 \mathrm{~V}$ and it may be attributed to the following redox reaction [32]:

$$
\begin{aligned}
& \text { at } 0.5 \mathrm{~V} \text {, } \\
& \qquad \mathrm{Ni}(\mathrm{OH})_{2}+\mathrm{OH}^{-} \longleftrightarrow \mathrm{NiOOH}+\mathrm{H}_{2} \mathrm{O}+\mathrm{e}^{-}
\end{aligned}
$$

Modified gold electrode with $\mathrm{MnO}$ single catalyst showed two significant reduction peaks at $0.254 \mathrm{~V}$ and $-0.558 \mathrm{~V}$. The reduction peaks are attributable to the following equations [33]:

at $0.254 \mathrm{~V}$,

$$
\mathrm{MnO}_{2}+\mathrm{H}^{+}+\mathrm{e}^{-} \longrightarrow \mathrm{MnOOH}
$$




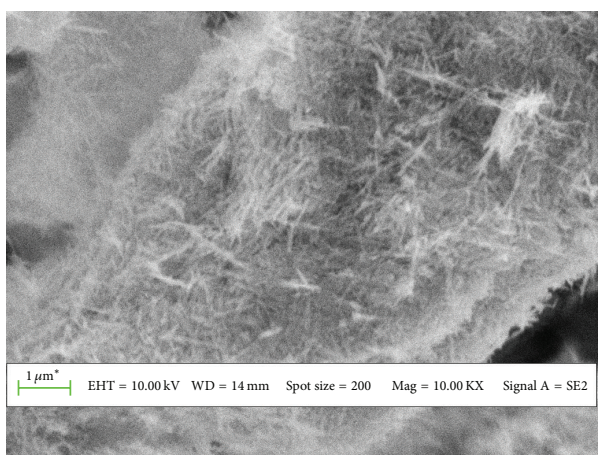

(a)

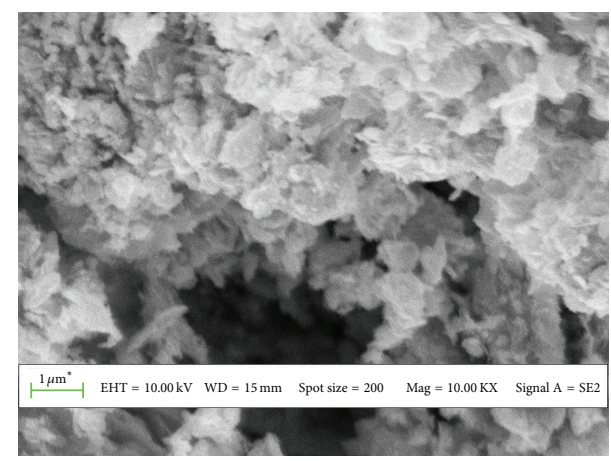

(b)

FIGURE 4: SEM images for (a) nickel oxide; (b) manganese oxide.

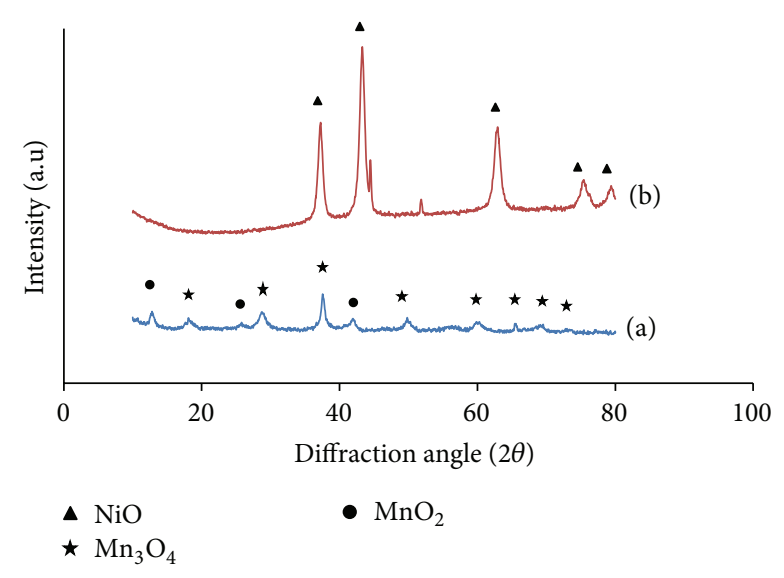

FIGURE 5: XRD patterns of (a) manganese oxide; (b) nickel oxide.

at $-0.558 \mathrm{~V}$,

$$
\mathrm{MnOOH}+3 \mathrm{H}^{+}+\mathrm{e}^{-} \longrightarrow \mathrm{Mn}^{2+}+2 \mathrm{H}_{2} \mathrm{O}_{2}
$$

Modified gold electrode with (NiO-MnO) binary catalyst showed a stable voltammetric response without oxidationreduction peaks.

Figure 7 shows amperometric response at different concentration of $\mathrm{H}_{2} \mathrm{O}_{2}$ for the modified gold electrodes. The modified gold electrode with binary catalyst showed highest amperometric response. The highest sensing activity by modified gold electrode with binary catalyst may be attributed to an increased number of $\mathrm{Ni}^{3+}$ active sites induced by MnO. El-Refaei et al. found that the electrocatalytic activity greatly improved when they used both $\mathrm{MnO}$ and $\mathrm{NiO}$ catalyst together for glucose oxidation. They also explained the significant role of $\mathrm{MnO}$ in changing catalytic activity of $\mathrm{NiO}$ [34]. $\mathrm{MnO}$ will convert $\mathrm{Ni}^{2+}$ to $\mathrm{Ni}^{3+}$; therefore it will increase the charge carrier concentration leading to an increased conductivity. The proposed hydrogen peroxide sensor displays a detection range from $31.8 \mu \mathrm{M}$ to $500 \mu \mathrm{M}$ with the detection limit of $62.5 \mu \mathrm{M}$.
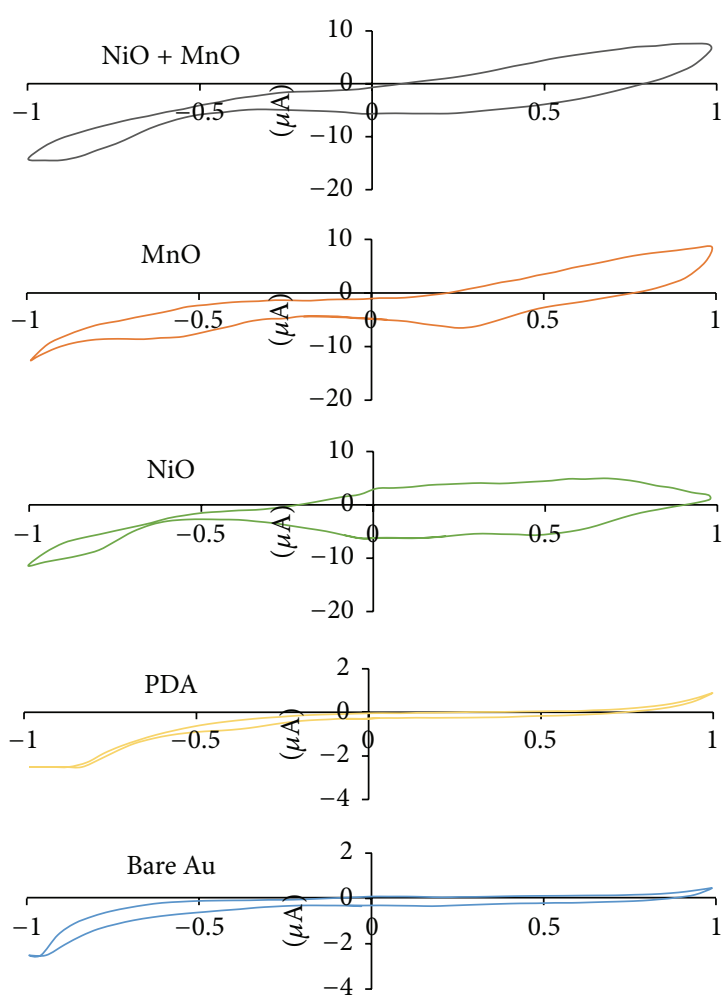

FIGURE 6: Cyclic voltammetry of modified gold electrodes from $-1 \mathrm{~V}$ to $+1 \mathrm{~V}$ at scan rate $50 \mathrm{mV} \mathrm{s}^{-1}$. All curves correspond to 3rd cycle.

\section{Conclusions}

A binary catalyst with nickel oxides nanowires and manganese oxides spherical nanoparticles was successfully synthesized via hydrothermal technique. A simple technique was used to fabricate all modified gold electrode for hydrogen peroxide detection. With a binary catalyst of $\mathrm{NiO}-\mathrm{MnO}$ modified gold electrode, the sensitivity of the sensors is enhanced in comparison with single catalyst modified gold electrodes. This can be attributable to the increased number of $\mathrm{Ni}^{3+}$ active sites induced by $\mathrm{MnO}$. However, modified gold electrode with single catalyst $\mathrm{NiO}$ has better linear response 


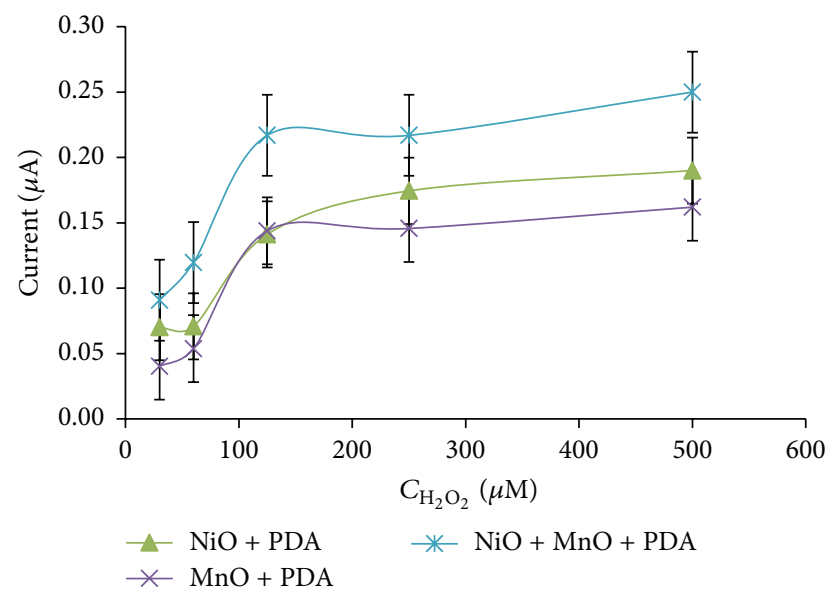

FIgURE 7: Amperometric response for modified gold electrodes with different concentration of $\mathrm{H}_{2} \mathrm{O}_{2}$ at applied potential of $0.7 \mathrm{~V}$.

to hydrogen peroxide if compared to modified gold electrode with binary catalyst.

\section{Conflict of Interests}

The authors declare that there is no conflict of interests regarding the publication of this paper.

\section{Acknowledgments}

Suriani greatly acknowledge financial support from Japan International Cooperation Agency Project Office (JICA) with Grant no. CU CR1201 and Electrical Engineering Department, Faculty of Engineering, Chulalongkorn University, for their support on this project. The authors also would like to thank Bioptik Technology, Inc. for providing them with gold electrodes for this project.

\section{References}

[1] T. Henzler and E. Steudle, "Transport and metabolic degradation of hydrogen peroxide in Chara corallina: model calculations and measurements with the pressure probe suggest transport of $\mathrm{H}_{2} \mathrm{O}_{2}$ across water channels," Journal of Experimental Botany, vol. 51, no. 353, pp. 2053-2066, 2000.

[2] T. Lindahl, "Instability and decay of the primary structure of DNA," Nature, vol. 362, no. 6422, pp. 709-715, 1993.

[3] Y. Luo, H. Liu, Q. Rui, and Y. Tian, "Detection of extracellular $\mathrm{H}_{2} \mathrm{O}_{2}$ released from human liver cancer cells based on $\mathrm{TiO}_{2}$ nanoneedles with enhanced electron transfer of cytochrome c," Analytical Chemistry, vol. 81, no. 8, pp. 3035-3041, 2009.

[4] L. Mao, P. G. Osborne, K. Yamamoto, and T. Kato, "Continuous on-line measurement of cerebral hydrogen peroxide using enzyme-modified ring-disk plastic carbon film electrode," Analytical Chemistry, vol. 74, no. 15, pp. 3684-3689, 2002.

[5] X. H. Kang, Z. B. Mai, X. Y. Zou, P. X. Cai, and J. Y. Mo, "A novel glucose biosensor based on immobilization of glucose oxidase in chitosan on a glassy carbon electrode modified with gold-platinum alloy nanoparticles/multiwall carbon nanotubes," Analytical Biochemistry, vol. 369, no. 1, pp. 71-79, 2007.
[6] V. S. Tripathi, V. B. Kandimalla, and H. Ju, "Amperometric biosensor for hydrogen peroxide based on ferrocene-bovine serum albumin and multiwall carbon nanotube modified ormosil composite," Biosensors and Bioelectronics, vol. 21, no. 8, pp. 1529-1535, 2006.

[7] M. A. Siddiqui, M. Ahamed, J. Ahmad et al., "Nickel oxide nanoparticles induce cytotoxicity, oxidative stress and apoptosis in cultured human cells that is abrogated by the dietary antioxidant curcumin," Food and Chemical Toxicology, vol. 50, no. 3-4, pp. 641-647, 2012.

[8] W. Wang, C. Su, R. Ran, and Z. Shao, "A new Gd-promoted nickel catalyst for methane conversion to syngas and as an anode functional layer in a solid oxide fuel cell," Journal of Power Sources, vol. 196, no. 8, pp. 3855-3862, 2011.

[9] E. Sharifi, A. Salimi, E. Shams, A. Noorbakhsh, and M. K. Amini, "Shape-dependent electron transfer kinetics and catalytic activity of $\mathrm{NiO}$ nanoparticles immobilized onto DNA modified electrode: fabrication of highly sensitive enzymeless glucose sensor," Biosensors and Bioelectronics, vol. 56, pp. 313319, 2014.

[10] Y. Qiao, X.-S. Wu, and C. M. Li, "Interfacial electron transfer of Shewanella putrefaciens enhanced by nanoflaky nickel oxide array in microbial fuel cells," Journal of Power Sources, vol. 266, pp. 226-231, 2014.

[11] A. Salimi, E. Sharifi, A. Noorbakhsh, and S. Soltanian, "Immobilization of glucose oxidase on electrodeposited nickel oxide nanoparticles: direct electron transfer and electrocatalytic activity," Biosensors and Bioelectronics, vol. 22, no. 12, pp. 3146-3153, 2007.

[12] J. Song, L. Xu, R. Xing, W. Qin, Q. Dai, and H. Song, "Ag nanoparticles coated $\mathrm{NiO}$ nanowires hierarchical nanocomposites electrode for nonenzymatic glucose biosensing," Sensors and Actuators B: Chemical, vol. 182, pp. 675-681, 2013.

[13] Y. Ding, Y. Wang, L. Su, H. Zhang, and Y. Lei, "Preparation and characterization of $\mathrm{NiO}-\mathrm{Ag}$ nanofibers, $\mathrm{NiO}$ nanofibers, and porous Ag: towards the development of a highly sensitive and selective non-enzymatic glucose sensor," Journal of Materials Chemistry, vol. 20, no. 44, pp. 9918-9926, 2010.

[14] S. M. Majd, H. Teymourian, A. Salimi, and R. Hallaj, "Fabrication of electrochemical theophylline sensor based on manganese oxide nanoparticles/ionic liquid/chitosan nanocomposite modified glassy carbon electrode," Electrochimica Acta, vol. 108, pp. 707-716, 2013.

[15] V. F. Espí, A. A. Paneque, M. Torrens, A. J. O. González, and E. Reguera, "Conjugation of manganese ferrite nanoparticles to an anti Sticholysin monoclonal antibody and conjugate applications," Colloids and Surfaces A: Physicochemical and Engineering Aspects, vol. 387, no. 1-3, pp. 118-124, 2011.

[16] H. A. Ngwa, A. Kanthasamy, Y. Gu, N. Fang, V. Anantharam, and A. G. Kanthasamy, "Manganese nanoparticle activates mitochondrial dependent apoptotic signaling and autophagy in dopaminergic neuronal cells," Toxicology and Applied Pharmacology, vol. 256, no. 3, pp. 227-240, 2011.

[17] Y. Li, J. Zhang, H. Zhu, F. Yang, and X. Yang, "Gold nanoparticles mediate the assembly of manganese dioxide nanoparticles for $\mathrm{H}_{2} \mathrm{O}_{2}$ amperometric sensing," Electrochimica Acta, vol. 55, no. 18 , pp. 5123-5128, 2010.

[18] C. M. Zhou, H. J. Wang, F. Peng, J. H. Liang, H. Yu, and J. Yang, " $\mathrm{MnO}_{2} / \mathrm{CNT}$ supported $\mathrm{Pt}$ and PtRu nanocatalysts for direct methanol fuel cells," Langmuir, vol. 25, no. 13, pp. 7711-7717, 2009. 
[19] Y. Huang, J. D. Cai, and Y. L. Guo, "Roles of $\mathrm{Pb}$ and $\mathrm{MnO}_{x}$ in $\mathrm{PtPb} / \mathrm{MnO}_{x}-\mathrm{CNTs}$ catalyst for methanol electro-oxidation," International Journal of Hydrogen Energy, vol. 37, no. 2, pp. 12631271, 2012.

[20] J. L. Dalsin, B.-H. Hu, B. P. Lee, and P. B. Messersmith, "Mussel adhesive protein mimetic polymers for the preparation of nonfouling surfaces," Journal of the American Chemical Society, vol. 125, no. 14, pp. 4253-4258, 2003.

[21] Y. G. Zhang, Z. F. Qin, G. F. Wang et al., "Catalytic performance of $\mathrm{MnO}_{x}-\mathrm{NiO}$ composite oxide in lean methane combustion at low temperature," Applied Catalysis B: Environmental, vol. 129, pp. 172-181, 2013.

[22] G. Róg and A. Kozłowska-Róg, "Determination of the activities in $\{x \mathrm{MnO}+(1-x) \mathrm{NiO}\}$ by solid-electrolyte galvanic cells in the temperature range $973 \mathrm{~K}$ to $1173 \mathrm{~K}$," Journal of Chemical Thermodynamics, vol. 29, no. 3, pp. 305-310, 1997.

[23] M. Yang, Q. Ling, R. Rao et al., " $\mathrm{Mn}_{3} \mathrm{O}_{4}-\mathrm{NiO}-\mathrm{Ni} / \mathrm{CNT}$ catalysts prepared by spontaneous redox at high temperature and their superior catalytic performance in selective oxidation of benzyl alcohol," Journal of Molecular Catalysis A: Chemical, vol. 380, pp. 61-69, 2013.

[24] B. J. Zhang, W. Y. Li, J. Q. Sun et al., " $\mathrm{NiO} / \mathrm{MnO}_{2}$ core/shell nanocomposites for high-performance pseudocapacitors," Materials Letters, vol. 114, pp. 40-43, 2014.

[25] C. J. Xu, K. M. Xu, H. W. Gu et al., "Dopamine as a robust anchor to immobilize functional molecules on the iron oxide shell of magnetic nanoparticles," Journal of the American Chemical Society, vol. 126, no. 32, pp. 9938-9939, 2004.

[26] H. Lee, S. M. Dellatore, W. M. Miller, and P. B. Messersmith, "Mussel-inspired surface chemistry for multifunctional coatings," Science, vol. 318, no. 5849, pp. 426-430, 2007.

[27] H. D. Jang, S. K. Kim, H. W. Chang, K.-M. Roh, J.-W. Choi, and J. X. Huang, "A glucose biosensor based on $\mathrm{TiO}_{2}$-graphene composite," Biosensors and Bioelectronics, vol. 38, no. 1, pp. 184188, 2012.

[28] A. Gao, Y.-R. Wang, X.-W. He, and X.-B. Yin, "An Electrochemical hydrogen peroxide biosensor based on polydopamineentrapped g-Quadruplex-Hemin DNAzyme," Chinese Journal of Analytical Chemistry, vol. 40, no. 10, pp. 1471-1476, 2012.

[29] D. Mohammadyani, S. A. Hosseini, and S. K. Sadrnezhaad, "Characterization of Nickel Nanoparticles synthesized Via rapid microwave-assisted route," International Journal of Modern Physics, vol. 5, pp. 270-276, 2012.

[30] Y.-Y. Hu, Z.-Y. Wen, and J. Jin, "Rapid low-cost synthesis and enhanced electrochemical properties of mesoporous $\mathrm{Mn}_{3} \mathrm{O}_{4}$ nanorods," Journal of Inorganic Materials, vol. 28, no. 9, pp. 1045-1050, 2013.

[31] S. Ming, L. Bang, L. Ting et al., "Controlled synthesis of nanostructured manganese oxide: crystalline evolution and catalytic activities," CrystEngComm, vol. 15, no. 35, pp. 70107018, 2013.

[32] D. E. Pissinis, L. E. Sereno, and J. M. Marioli, "Utilization of special potential scan programs for cyclic voltammetric development of different nickel oxide-hydroxide species on $\mathrm{Ni}$ based electrode," Open Journal of Physical Chemistry, vol. 2, pp. 23-33, 2012.

[33] S. Devaraj and N. Munichandraiah, "EQCM investigation of the electrodeposition of $\mathrm{MnO}_{2}$ and its capacitance behavior," Electrochemical and Solid-State Letters, vol. 12, no. 9, pp. F21F25, 2009.

[34] S. M. El-Refaei, M. I. Awad, B. E. El-Anadouli, and M. M. Saleh, "Electrocatalytic glucose oxidation at binary catalyst of nickel and manganese oxides nanoparticles modified glassy carbon electrode: optimization of the loading level and order of deposition," Electrochimica Acta, vol. 92, pp. 460-467, 2013. 

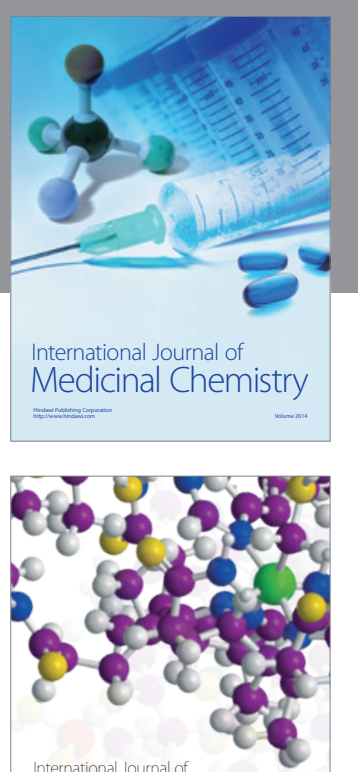

Carbohydrate Chemistry

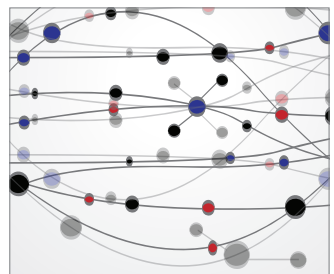

The Scientific World Journal
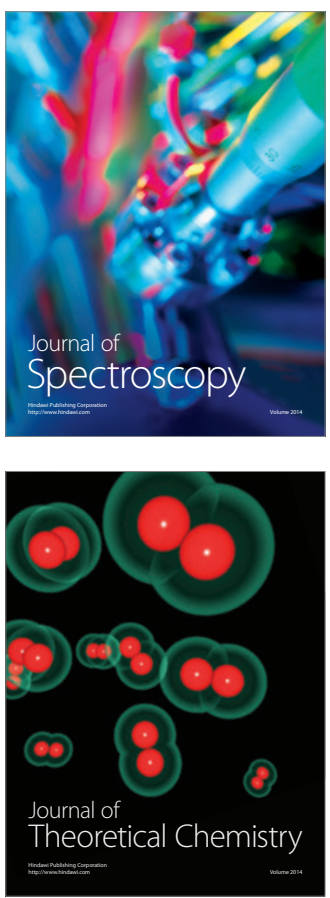
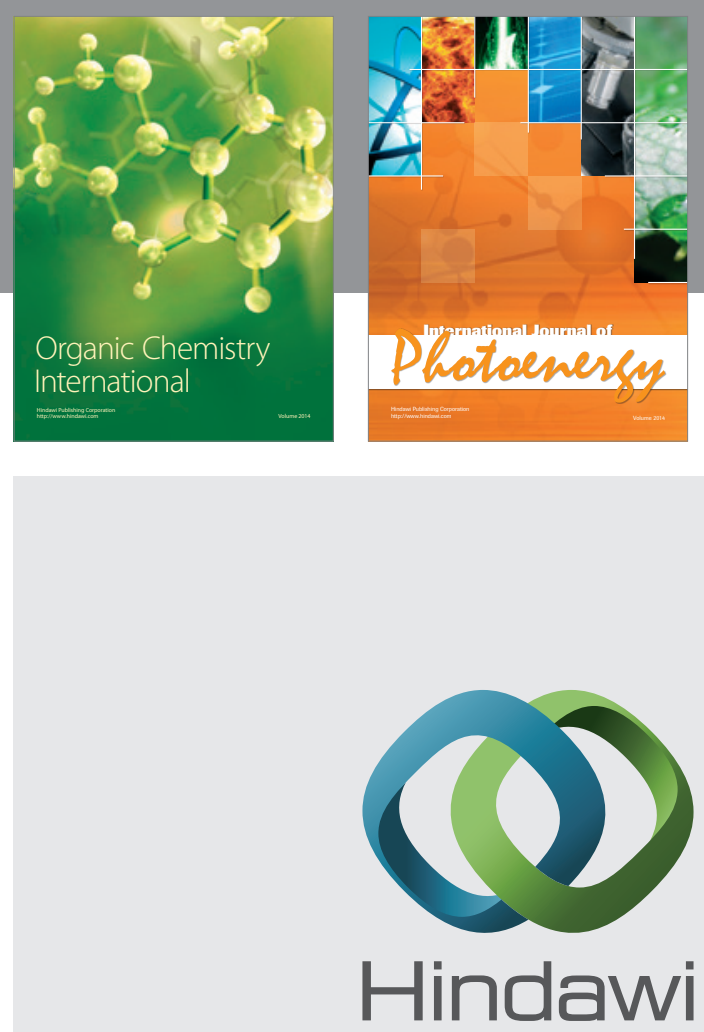

Submit your manuscripts at

http://www.hindawi.com

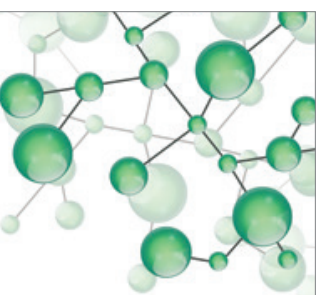

International Journal of

Inorganic Chemistry

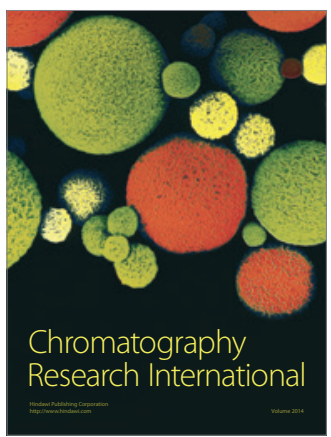

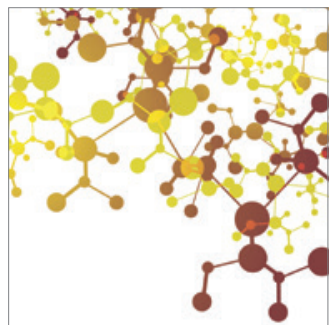

Applied Chemistry
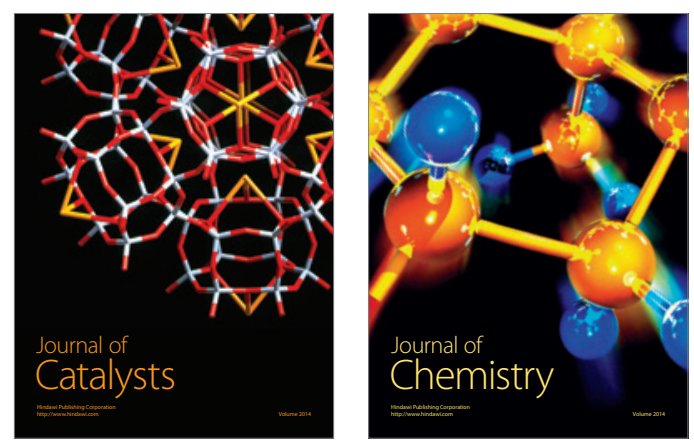
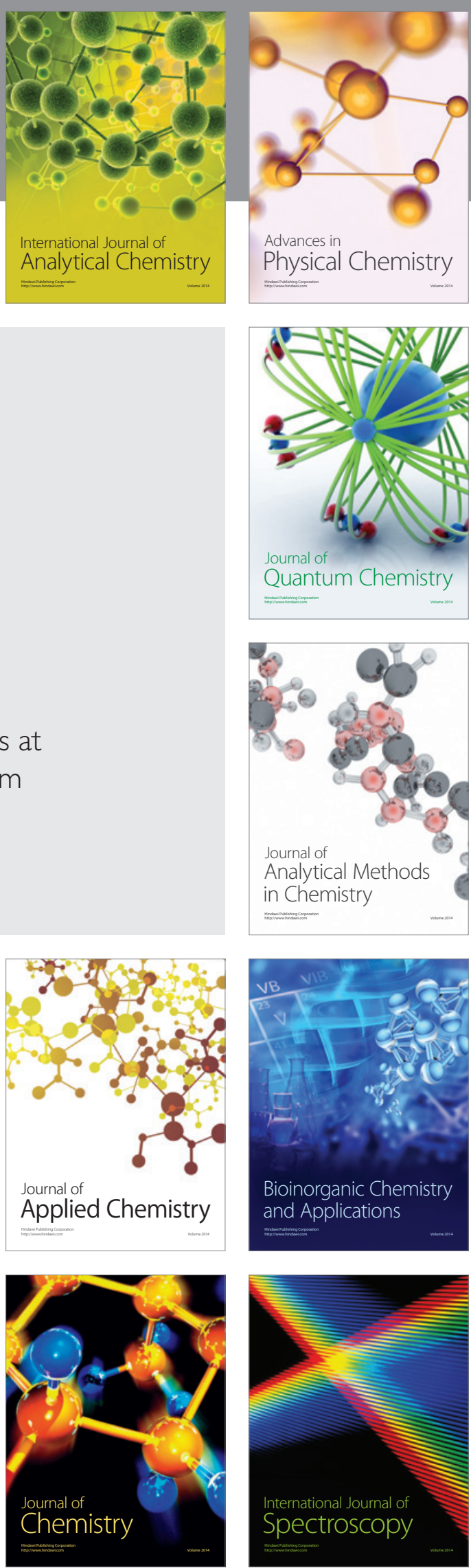